the summary suspension automatically became a Revocation on 7 December 2016.

On 26 May 2016, in a federal court hearing in New York City, Parietti admitted that between 2006 and 2008 , while employed as a trader with Deutsche Bank US Financial Markets, he participated in a scheme to manipulate the London Interbank Offered Rate (LIBOR). He pleaded guilty to felony charges of conspiring to commit wire fraud and bank fraud.

On 30 January 2017, CFA Institute imposed a Summary Suspension on Gordon D. Brooks (Cathedral City, California), a charterholder member, automatically suspending his membership and right to use the CFA designation. Because he did not request a review, the summary suspension became a Revocation on 27 February 2017.

Brooks was summarily suspended for his failure to cooperate with a Professional Conduct investigation regarding the suitability of investments sold to a former client. Because he failed to cooperate, Professional Conduct was unable to determine whether Brooks violated the CFA Institute Code of Ethics and Standards of Professional Conduct.

On 29 August 2016, CFA Institute imposed a Summary Suspension on Yugo Matsumoto (Tokyo, Japan), a lapsed charterholder member, automatically suspending his right to reactivate his membership and use the CFA designation. Matsumoto was suspended for his failure to cooperate with a Professional Conduct investigation. A Hearing Panel affirmed the summary suspension, which then automatically became a Revocation on 13 January 2017.

Matsumoto disclosed to CFA Institute that he was involved in an internal investigation by his former employer, UBS Securities Japan Co., Ltd., related to his possible involvement in LIBOR and Tokyo Interbank Offered Rate rigging. Later, media reports also suggested that Matsumoto may have been involved in misconduct relating to the rigging of interest rate benchmarks. Because of his failure to cooperate, Professional Conduct was unable to investigate the matter and determine whether Matsumoto had violated the CFA Institute Code of Ethics and Standards of Professional Conduct.

\section{CENSURE}

Effective 2 March 2017, CFA Institute imposed a Censure on Kefei Wang (Beijing, China), a charterholder member. CFA Institute found that Wang violated the CFA Institute Code of Ethics and Standards of Professional Conduct: I(A) - Knowledge of the Law (2014).

The US Congress created the Immigrant Investor Program, also known as the "EB-5 Program," to stimulate the economy through job creation and capital investment by foreign investors. EB- 5 investments are typically offered as limited partnership interests. From January 2010 through May 2014, Wang received $\$ 40,000$, which constituted his portion of the commissions received from one EB-5 Investment Offeror. These commissions were paid pursuant to a written agency agreement between Wang's company, Nautilus Global Capital LLC, and the EB-5 Investment Offeror.

On 7 December 2015, the SEC issued a Ceaseand-Desist Order against Wang. The SEC determined that Wang had violated Section 15(a)(1) of the Exchange Act, which makes it unlawful for anyone not associated with a registered broker or dealer to make use of the mails or any instrumentality of interstate commerce "to effect any transactions in, or to induce or attempt to induce the purchase or sale of, any security" unless such party is registered in accordance with the act. Wang was not associated with a registered broker or dealer. As a result, the SEC required that Wang cease and desist from committing or causing any violations of Section 15(a) (1) and pay disgorgement of $\$ 40,000$, pre-judgment interest of $\$ 1,590$, and a civil money penalty of $\$ 25,000$.

\section{RESIGNATION}

Effective 30 January 2017, a Candidate who had passed Level III of the CFA exam permanently withdrew his application for membership in CFA Institute and any member society during the course of an investigation by Professional Conduct to determine whether he wrote a research report that appeared online in which he made statements about a publicly traded company for which he lacked a reasonable basis and independence and objectivity.
Effective 7 March 2017, Ronald L. Strauss (Chicago), a lapsed charterholder member, permanently resigned his membership in CFA Institute and any member society during the course of a Professional Conduct investigation regarding findings made by the SEC that from 2009 until 2011 he dedicated insufficient resources to compliance, which contributed to multiple compliance failures at the investment advisory firm where he served as president until his retirement in 2014.

Effective 13 March 2017, David E. West (Homer Glen, Illinois), a lapsed charterholder member, permanently resigned his right to reactivate his membership in CFA Institute and any member societies and his right to use the CFA designation, during the course of a Professional Conduct investigation.

\section{RESCISSION}

On 9 January 2017, Professional Conduct rescinded the Revocation that CFA Institute had imposed on Spyridon G. "Sam" Adondakis (New York City), a charterholder member. Adondakis' membership and right to use the CFA designation were summarily suspended in March 2012. That suspension automatically became a revocation when he failed to request a review at that time. The summary suspension was imposed after it was revealed that Adondakis had pleaded guilty to felony charges relating to his participation in a fraudulent scheme with fund managers and research analysts at five different firms to share material nonpublic information and engage in insider trading.

Adondakis' request for rescission of the revocation was granted after he provided documents showing that the felony charges filed against him by the US Attorney's Office had been dismissed nolle prosequi and an order previously entered by the district court in connection with his settlement of a related civil matter brought by the SEC had been vacated. These actions resulted from a decision issued by the US Court of Appeals for the Second Circuit that found that the transactions that were the basis for the entry of judgment against Adondakis did not constitute illegal insider trading. The US Supreme Court subsequently denied the government's petition for review of that decision.

\title{
Historical Curiosities of Wall Street: A Brief Guide
}

\author{
By Ralph Wanger, CFA
}

A few weeks ago, one of my friends sent me an ancient book: Men and Mysteries of Wall Street by James Medbery, published in 1870. I told my friend that I had gone into the mutual fund business in 1970, not 1870, but he knew I was a history buff. In 1870 , the United States was a very different country, and the NYSE was a speculator's playground. The Civil War had ended only five years earlier, and President Grant had the Federal Army trying to suppress the Ku Klux Klan in the South. The leading technology was the rapidly expanding railroad network; the transcontinental railroad had just linked California with the eastern states in 1869, allowing for easy settlement of the western US for the first time.

Trading on the New York Stock Exchange at that time reflected the popularity of railroads. Most of the listed stocks were railroad companies. The whole market was very speculative: individuals trading on margin, lots of short selling. Bull- and bear-market speculators made fortunes, only to go broke a few months later. Almost no financial information was available to the public except for the dividend on a stock-rumors and market-share corners created an atmosphere that was much more like a commodity trading floor than the sedate industry we have now. 
The enabling technology for the stock market was the telegraph; it allowed for instant communication across the country, and by 1858 , across the ocean as well. Before 1840, news traveled only as fast as a sailing ship could carry a mail sack. This lag allowed some colorful arbitrage opportunities. For example, in 1820, the NYSE was just being organized as a practical enterprise, copying the successful Philadelphia Board. Three traders from New York hired a stagecoach to take them to Philadelphia. Just before they left, a ship from London arrived with bullish news. While on the stagecoach, the traders realized that Philadelphia could not have heard this news yet, so they sped to Philly before the market closed and bought all the stock they could. The three scalped a nice profit, because the unsuspecting Pennsylvanians had not heard the London news.

Some of the shrewdest and most crooked traders of the day were Daniel Drew, Jim Fisk, and Jay Gould. They loved to manipulate Erie Railroad stock. Though the Erie was a marginal railroad, Erie stock was a marvelous toy for speculators. The book mentions William M. Tweed as a rising stockbroker. He was also becoming a major political figure and ran New York City as "Boss" Tweed in the 1870s. Tweed conspired with Fisk and Gould to swindle Cornelius Vanderbilt out of his control of the Erie by counterfeiting Erie stock (a marvelous bit of skullduggery described by Henry Adams in Chapters of Erie in 1871).

Thomas Durant, a vice president at Union Pacific Railroad, had "an enviable reputation for financial boldness, quickness, insight, and Dantonian audacity in execution"meaning that he constructed several railroads while building his own fortune as well. He was one of the first to realize that constructing a railroad was a different business from operating a railroad. In 1864, when it was time to start building the First Transcontinental Railroad, he separated the Union Pacific Railroad from the construction company, Crédit Mobilier. Durant hired Major General Grenville Dodge, who ran the railroads in the occupied South during the Civil War, as the construction manager. Dodge laid track across the prairies at an astounding four to seven miles per day, forcing Crédit Mobilier to sell an enormous quantity of bonds to finance the construction. Durant appears to have siphoned a little too much money out of the project and was fired in 1869, but the US got its railroad.

The Jerome brothers, Addison and Leonard, grew up on a small farm in upstate New York and then moved to New York City in the 1850s to make their fortune. Unfortunately, Addison died young, but his younger brother Leonard went on to pioneer the stock-tout business, writing financial news for James Gordon Bennett of the New York Herald. Along with an old business and social friend of Addison's, August

Belmont, Leonard built the Jerome Park Racetrack. The Belmont Stakes was first run at that track in 1867.

Leonard Jerome had three lovely daughters, who were raised in upper-class New York circles. Jeanette, known as Jennie, was very fond of Europe and went to London, where she met and married Lord Randolph Churchill, a British statesman. Shortly after their marriage, she gave birth to Winston Churchill, whose exploits are too long for this column.

The aforementioned August Belmont was born in Germany to a Jewish family named Schönberg. He came to New York City in 1837 and became the American agent for the Rothschild banking family. Belmont became wealthy and was named a diplomat. He married Caroline Perry in 1849. Caroline's father was a naval officer who became worldfamous in 1853 when, as Commodore Perry, he commanded the expedition that opened up the trading ports in Japan.

The climax of the Medbery book was a sensational bull corner in the gold market. Because the country was on the gold standard, there was always speculation about Treasury programs to buy or sell gold bullion. Our friends Fisk and Gould bought gold heavily, attracting short sellers. The ring kept buying gold, creating a corner, a short squeeze that broke the bears. A Congressional investigation of the affair took place after Medbery's book had been published. Major government officials at the Treasury and the White House were implicated, tainting the Grant administration's reputation to this day.

Ralph Wanger, CFA, is an honorary trustee of Columbia Acorn Trust. 